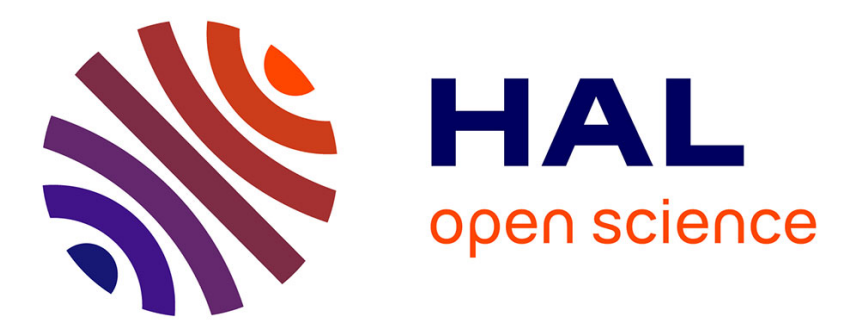

\title{
Autosomal dominant SPG9: intrafamilial variability and onset during pregnancy
}

Cécilia Marelli, Stéphanie Badiou, Steeve Genestet, L. Larrieu, P. Damier, W. Camu, M. Planes, Michel Koenig, C. Guissart

\section{- To cite this version:}

Cécilia Marelli, Stéphanie Badiou, Steeve Genestet, L. Larrieu, P. Damier, et al.. Autosomal dominant SPG9: intrafamilial variability and onset during pregnancy. Neurological Sciences, In press, 41 (7), pp.1931-1933. 10.1007/s10072-020-04341-5 . hal-02524578

\section{HAL Id: hal-02524578 \\ https://hal.science/hal-02524578}

Submitted on 4 Aug 2021

HAL is a multi-disciplinary open access archive for the deposit and dissemination of scientific research documents, whether they are published or not. The documents may come from teaching and research institutions in France or abroad, or from public or private research centers.
L'archive ouverte pluridisciplinaire HAL, est destinée au dépôt et à la diffusion de documents scientifiques de niveau recherche, publiés ou non, émanant des établissements d'enseignement et de recherche français ou étrangers, des laboratoires publics ou privés. 


\title{
Autosomal dominant SPG9: intrafamilial variability and onset during pregnancy
}

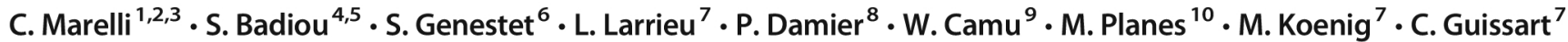

\begin{abstract}
Introduction The ALDH18A1 gene, encoding delta-1-pyrroline-5-carboxylate synthase (P5CS), is responsible for an autosomal recessive disease with severe developmental delay; more recently, ALDH18Al was found to be responsible for SPG9, an autosomal dominant (AD) spastic paraplegia.

Case report We report a three-generation family with AD SPG9, initially suspected because of low citrulline on fasting plasma amino acid chromatography (AAC). Interestingly, in two patients, the spastic paraplegia appeared during pregnancy. One subject presented a severe childhood-onset form while another subject had a mild late-onset disease.

Conclusion The description of this family is of particular interest: it highlights the possibility of transient or permanent aggravation of spastic paraplegia due to SPG9 during pregnancy, suggesting a direct link between neurological symptoms and amino acid defect in a period of higher requirements and the potential benefit of amino acid supplementation; it underscores the value of plasma citrulline on fasting plasma $\mathrm{AAC}$ as a biomarker for this disease; it shows the variable expression of the disease.
\end{abstract}

Keywords Genetics $\cdot$ Metabolic diseases (inherited) $\cdot$ Spastic paraplegia

\section{Short report}

A 39-year-old woman consulted because of spastic paraplegia, which appeared as progressive fatigue and leg stiffness during her first pregnancy, at the age of 28 . After delivery, the symptoms persisted and were aggravated after a fall with double malleolus fracture; 1 year later, she required two canes, and 4 years later, she was wheelchair-bound. Neurological examination showed tetra-hyperreflexia with severe lower limb spasticity and weakness and distal upper limb weakness with thenar hypotrophy. She had short stature and no cognitive impairment.

C. Marelli

c-marelli@chu-montpellier.fr

1 Department of Neurology, Expert Centre for Neurogenetic Diseases and Adult Mitochondrial and Metabolic Diseases, Gui de Chauliac University Hospital Montpellier, 80, Avenue A Fliche, 34295 Montpellier, France

2 Laboratoire de Génétique de Maladies Rares EA7402, Institut Universitaire de Recherche Clinique, Université de Montpellier, Montpellier, France

Inserm U1198 MMDN, Montpellier, France
Her sister also suffers from spastic paraplegia, still allowing autonomous walking, which appeared during her 4th pregnancy, at the age of 37 years. The eldest child of the sister suffers from global severe motor and cognitive developmental delay with microcephaly, short stature, epilepsy, ataxia, and spasticity; no problems were reported during pregnancy and delivery. The proband's mother also suffers from progressive spastic paraplegia since the age of 50, with autonomous walking still possible (Fig. 1a).

The proband (III7) had mild spinal cord atrophy but no cortical atrophy (Fig. 1c) and normal EMG. A genetic form

5 PhyMedExp, INSERM, CNRS, CHU de Montpellier, Université de Montpellier, Montpellier, France

6 Hôpital de la Cavale Blanche, Service d'Explorations Fonctionnelles Neurologiques, CHRU de Brest, 29609 Brest, France

7 Institut Universitaire de Recherche Clinique, Laboratoire de Génétique de Maladies Rares EA7402, Laboratoire de Génétique Moléculaire, University Hospital, Université de Montpellier, Montpellier, France

8 Service de Neurologie, CHU de Nantes, Nantes, France

9 Expert Center for Motor Neuron Diseases, Explorations Neurologiques, CHU and Université de Montpellier, Montpellier, France

10 Service de Genetique Clinique, CHRU Morvan, 29609 Brest, France 


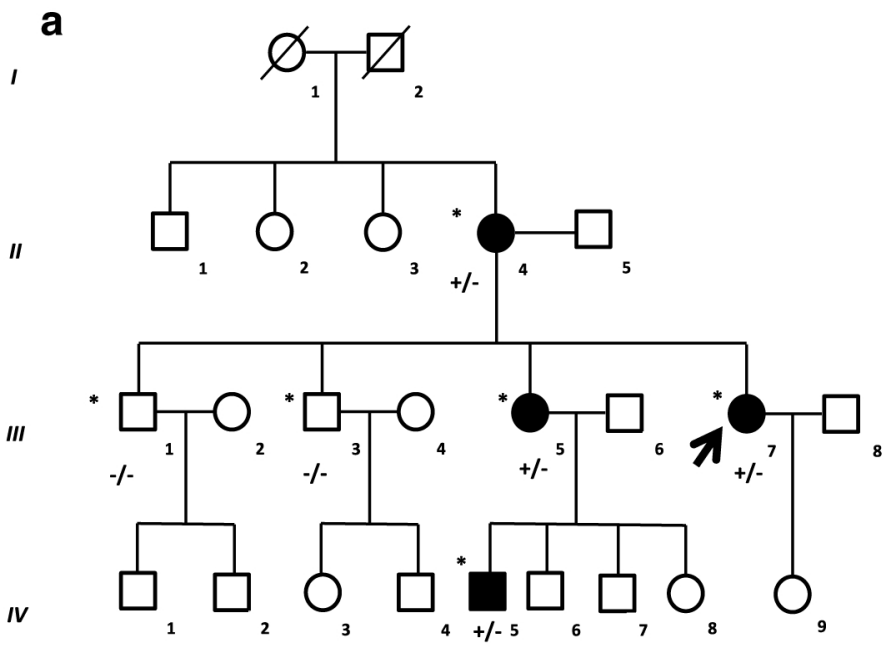

b

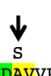

HELLRMNIVP IVNTTNDAVVPPAEPNSDLQGVNV---ISVKDNDSLAARLAVEMK homo $s$ SELISLNIVPI INTNDAVSPPMFIRDDEPAGGARRGIPIKDNDSLSAMLAAEVQ drosophila m EELIHMHCIPIVNANDVVAPOPSPDVDLSGI------ISLKDNDSLAAMFAVQMN hydra $\mathrm{v}$ EALISMKCIPIINENDAVAPPPGLDQDLAGV-----ISLKDNDSLAALLAVEIR nematostella v NDLIFMRMTPIINGNDVVAPPKGKAMLRMRVIPVFNENDAISTRRAPYKDST-----GIFWDNDSLAALI SIFLK arabidops is KAMLRRVI TH LNLLELDVPIVINDASASDG---

Fig. 1 a Pedigree of the family showing the segregation of the c.670G $>$ T, p.Ala224Ser mutation in the ALDH18A1 gene. Sampled individuals are indicated with an asterisk. Individuals with the mutation are indicated as $+/-$; individuals without the mutation are indicated as $-/-$. b Amino acid sequence (single letter code) alignment of part of the glutamate kinase domain of human delta-1-pyrroline-5-carboxylate synthase with the sequence of orthologs from distant metazoan species, plants, and amoeba. Invariant residues are highlighted in green, and highly conserved residues
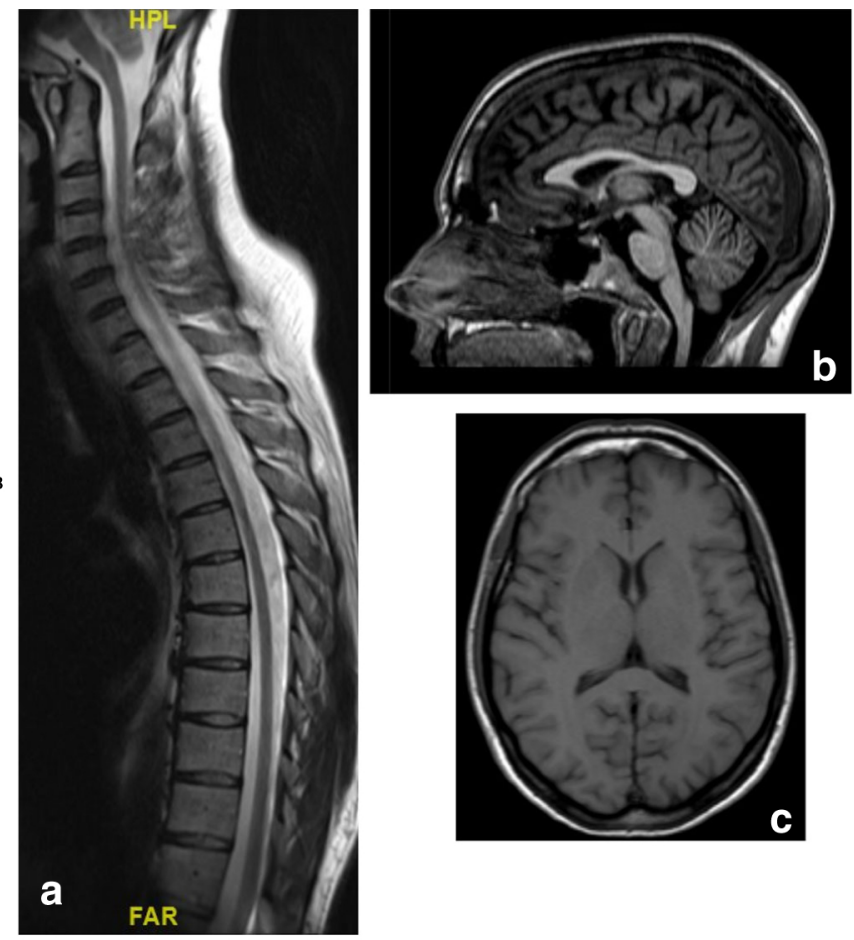

are highlighted in yellow; selected conservative amino acid changes are also highlighted. An arrow indicates alanine 224 (A), which is a conserved amino acid and which is mutated into serine (S) (SIFT score $=0$; PolyPhen$2=0.944)$. c Spinal and cerebral magnetic resonance images of the proband (subject III 7). (A) sagittal T2-weighted images showing mild global atrophy of the spinal cord. (B) Sagittal Flair-weighted image showing mild hypoplasia of the corpus of corpus callosum. (C) Axial T1-weighted image showing the absence of cortical atrophy

Table 1 Comparison of the principal disease features in the reported patients with SPG9A

$\begin{array}{lll}\text { Coutelier et al. [3] } & \text { Slavotinek et al. [4] } & \begin{array}{l}\text { Seri et al. [5]; } \\ \text { Panza et al. [6] }\end{array}\end{array} \quad$ Present report

\begin{tabular}{|c|c|c|c|c|}
\hline Patients & $n=15$ (3 families; 2 sporadic $)$ & $n=9$ (1 family $)$ & $n=13$ (1 family) & $n=4$ (1 family) \\
\hline Mutations & $\begin{array}{l}\text { p.Val120Ala; p.Arg665Leu; } \\
\text { p.Arg252Gln } \\
\text { p.Ser652Phe }\end{array}$ & p.Arg252Gln & p.Val243Leu & p.Ala224Ser \\
\hline Age at onset & $1-49$ years & 8 months-adult & 4 years-adult & Early childhood -50 years \\
\hline $\begin{array}{l}\text { Lower limb pyramidal } \\
\text { syndrome/spasticity }\end{array}$ & All & $\begin{array}{l}\text { 4/9 (2 during } \\
\text { pregnancy) }\end{array}$ & $12 / 12$ ( 2 during pregnancy) & All (2 during pregnancy) \\
\hline Upper limb amyotrophy & NA & $1 / 9$ & $7 / 12$ & $1 / 4$ \\
\hline Mental retardation and/or dementia & 3 & $1 / 9$ & NA & $1 / 4$ \\
\hline Cataract & $3 / 15$ (one late) & $5 / 9$ & $10 / 12$ & $0 / 4$ \\
\hline Vomiting, gastroesophageal reflux & 1 & $2 / 9$ & $12 / 12$ & $0 / 4$ \\
\hline $\begin{array}{l}\text { Short stature, hip dysplasia, } \\
\text { osteoporosis }\end{array}$ & NA & $5 / 9$ & $2 / 12$ & $1 / 4$ \\
\hline $\begin{array}{l}\text { Plasma amino acid } \\
\text { chromatography (fasting state) }\end{array}$ & $\begin{array}{l}\downarrow \text { citrulline (4/4 patients) } \\
\quad \pm \text { low pro, orn, or arg; } \\
\quad \mathrm{N} \mathrm{NH}_{3}\end{array}$ & NA & $\begin{array}{l}\downarrow \text { citrulline }(4 / 6 \text { patients }) \pm \\
\quad \text { low pro, orn, or arg; } \mathrm{N} \mathrm{NH}_{3}\end{array}$ & $\begin{array}{l}\downarrow \text { citrulline }(3 / 3 \text { patients }) \\
\quad \pm \text { low pro, orn, or arg; } \\
\mathrm{N} \mathrm{NH}_{3}\end{array}$ \\
\hline
\end{tabular}

\footnotetext{
${ }^{\mathrm{a}}$ Mutation present in one family and in one sporadic patient
}

pro proline, orn ornithine, arg arginine, $\mathrm{NH}_{3}$ ammonium, $\mathrm{N}$ normal, $\mathrm{NA}$ not assessed 
of HSP was suspected, and a complete metabolic screening, mostly for recessive diseases, was normal. Interestingly, fasting plasma amino acid chromatography (AAC) showed low citrulline ( $7 \mu \mathrm{mol} / \mathrm{l}$, normal value (nv) $18-46$ ) and proline (70 $\mu \mathrm{mol} / \mathrm{l} ; \mathrm{nv}$ 90-260) with normal arginine, ornithine, and ammonia. These findings were confirmed in a second fasting sample, while a non-fasting AAC showed citrulline at the low normal limit $(20 \mu \mathrm{mol} / \mathrm{l})$. This prompted us to search for a mutation in the ALDH18A1 gene, responsible for SPG9 and encoding delta-1-pyrroline-5-carboxylate synthase (P5CS), an enzyme that catalyzes the first common steps of proline and ornithine biosynthesis from glutamate [1]. We found a new heterozygous mutation (NM_002860.3:c.670G>T; p.Ala224Ser), predicted to be likely pathogenic: the mutation is absent in controls (gnomAD); it involves a conserved amino acid (SIFT score $=0$; PolyPhen-2 $=0.944$ ) (Fig. 1a), located in the glutamate kinase domain. The segregation study in the family (Fig. 1a) allowed to subsequently confirm the mutation in the proband's mother (II4); in proband's sister (III5), also showing fasting plasma hypocitrullinemia $(11 \mu \mathrm{mol} / \mathrm{l})$; and in her affected son (IV5), showing low citrulline $(11 \mu \mathrm{mol} / \mathrm{l}$; normal values $20-34 \mu \mathrm{mol} / \mathrm{l})$, ornithine ( $36 \mu \mathrm{mol} / \mathrm{l}$; normal values $50-100 \mu \mathrm{mol} / \mathrm{l})$, and proline $(119 \mu \mathrm{mol} / \mathrm{l}$; normal values $150-224 \mu \mathrm{mol} / 1)$ in fasting plasma AAC. The mutation was not found in the two non-affected brothers (III1; III3).

SPG9 was initially described as an autosomal recessive (AR) disease characterized by severe developmental delay, epilepsy, cutis laxa, joint hyperlaxity, short stature, cataract, microcephaly, and mild or severe pyramidal syndrome [2]. Subsequently, it became clear that $A L D H 18 A 1$ was the causal gene in some families with autosomal dominant (AD) HSP [3-5]. This dominant form differs from the AR one and is characterized by a slowly progressive, but finally, severe HSP, with onset mostly in adolescence or adulthood; in some patients, motor neuropathy, spastic dysarthria, cerebellar signs, congenital cataracts, short stature, skeletal abnormalities, and learning difficulties were also reported (Table 1). The occurrence of $\mathrm{AD}$ or AR inheritance for the disease-causing effects of ALDH18A1 mutations appears to be mutationspecific [6]. In the AD form, the suspected mechanism of the disease is a less efficient P5CS enzymatic activity due to a dominant negative effect [6].

The description of this family with AD SPG9 is of particular interest. Firstly, it underscores the value of fasting plasma citrulline as a consistent diagnostic biomarker, useful for the screening of HSP of suspected metabolic origin $[3,6]$. Secondly, it highlights that some women with AD SPG9 experience transient or permanent aggravation of the spastic paraplegia during pregnancy $[4,5]$; although we cannot exclude a coincidental finding or an aggravation due to reduced motility during the period of the pregnancy, the recurrence of this finding suggests a direct link between neurological symptoms and amino acid defect in a period of higher protein requirement, and the potential benefit of amino acid supplementation. Thirdly, it shows the variable expression of the disease, ranging from the more frequent adult-onset HSP to the childhood-onset form with motor and cognitive developmental delay $[4,5]$. The potential benefit of a specific amino acid supplementation still needs to be evaluated.

Acknowledgments We would like to thank all the members of the family.

\section{Compliance with ethical standards}

Conflict of interest $\mathrm{CM}$ received honorary travel to attend scientific meetings from Biomarin and Actelion Pharmaceuticals and honorary for consultant activity (Biomarin); SB, SG, LL, WC, MP, MK, and CG have nothing to disclose.

Ethical approval The paper was written in accordance with the Helsinki Declaration (2013). A written consentement for genetic analysis and research was obtained from each participant.

\section{References}

1. Hu CA, Lin WW, Obie C, Valle D (1999) Molecular enzymology of mammalian delta1-pyrroline-5-carboxylate synthase. Alternative splice donor utilization generates isoforms with different sensitivity to ornithine inhibition. J Biol Chem 274:6754-6762

2. Baumgartner MR, Hu CA, Almashanu S et al (2000) Hyperammonemia with reduced ornithine, citrulline, arginine and proline: a new inborn error caused by a mutation in the gene encoding delta(1)-pyrroline-5-carboxylate synthase. Hum Mol Genet 9:2853-2858

3. Coutelier M, Goizet C, Durr A, Habarou F, Morais S, DionneLaporte A, Tao F, Konop J, Stoll M, Charles P, Jacoupy M, Matusiak R, Alonso I, Tallaksen C, Mairey M, Kennerson M, Gaussen M, Schule R, Janin M, Morice-Picard F, Durand CM, Depienne C, Calvas P, Coutinho P, Saudubray JM, Rouleau G, Brice A, Nicholson G, Darios F, Loureiro JL, Zuchner S, Ottolenghi C, Mochel F, Stevanin G (2015) Alteration of ornithine metabolism leads to dominant and recessive hereditary spastic paraplegia. Brain J Neurol 138:2191-2205. https://doi.org/10.1093/ brain/awv143

4. Slavotinek AM, Pike M, Mills K, Hurst JA (1996) Cataracts, motor system disorder, short stature, learning difficulties, and skeletal abnormalities: a new syndrome? Am J Med Genet 62:42-47. https:// doi.org/10.1002/(SICI)1096-8628(19960301)62:1<42::AIDAJMG9>3.0.CO;2-Y

5. Seri M, Cusano R, Forabosco P, Cinti R, Caroli F, Picco P, Bini R, Morra VB, de Michele G, Lerone M, Silengo M, Pela I, Borrone C, Romeo G, Devoto M (1999) Genetic mapping to 10q23.3-q24.2, in a large Italian pedigree, of a new syndrome showing bilateral cataracts, gastroesophageal reflux, and spastic paraparesis with amyotrophy. Am J Hum Genet 64:586-593. https://doi.org/10.1086/302241

6. Panza E, Escamilla-Honrubia JM, Marco-Marín C et al (2016) ALDH18A1 gene mutations cause dominant spastic paraplegia SPG9: loss of function effect and plausibility of a dominant negative mechanism. Brain J Neurol 139:e3. https://doi.org/10.1093/brain/awv247

Publisher's note Springer Nature remains neutral with regard to jurisdictional claims in published maps and institutional affiliations. 